\title{
The Precariat or Dependents: What is More Dangerous for Russia's Socioeconomic Development?
}

\author{
Alexander Maloletko* \\ Russian State Social University \\ RSSU \\ Moscow, Russia \\ Shadow.economy@gmail.com
}

\author{
Natalia Maloletko \\ Kikot Moscow University of the Ministry of the Interior of \\ Russia \\ Moscow, Russia \\ 1102505@gmail.com
}

\begin{abstract}
At present, a number of researchers conclude that at low levels of the class structure there is so-called 'Precariat', characterized by a low level of capital. Agreeing with this, modern research is devoted to identifying the features of the 'Precariat', manifested in national and sectoral labor markets.

The purpose of this paper is to try to answer the question whether 'Precariat' is a social and economic problem for Russia or whether it is a new reality.

Considering the stability of employment, the main sources of wages or various groups of the population and the number of these groups, the authors came to the conclusion that, in fact, the main social problem is not the 'Precariat', but the phenomenon that the authors called 'Dependiat' (derived from the word 'dependents'). The 'Dependiat' is characterized by employment of a significant group of population, whose income is permanent, stable and depends mainly on the national budget.
\end{abstract}

Keywords-'Precariat'; Employment; Income; Poverty; Dependent; National budget

\section{INTRODUCTION}

Recently, the problem of key approaches to determine poverty in Russia, the applied criteria and their relevance has become the subject of scientific discussions. The research problem (Pasechko, 2017) involves the contradiction between theoretical approaches to the study of the poverty scales and the practice of social policy aimed at poverty reduction [1].

The matter is that, as it will be shown in this article, more than $70 \%$ of the Russians needs to reach the set values of macroeconomic indicators. After all, the volume of GDP, gold and foreign exchange reserves and the structure of the national budget directly affect to the incomes of at least 100 million citizens of Russia.

However, macroeconomic indicators, which are undoubtedly needed to control and monitor short-term situations are influenced by many external factors. For example, a macroeconomic indicator of the oils prices is an important for the Russian budget. The change in the price of oil immediately affects the real incomes of the population of Russia.

In fact, the growth of the economy, and as a consequence the success of the fight against poverty, is provided not by macroeconomic factors, but by microeconomic factors such as support for entrepreneurship, small business access to credit, support for innovation, and training. Only in these conditions private capital is able to ensure long-term development and reduce the dependence of the population on the macroeconomic behavior of the government.

However, for the authorities it is more convenient to have more dependents on the national budget than to increase the share of private capital. The fact is that private capital, showing activity in business, becomes independent in politics. The money of private capital can be directed to support any political candidates or mass media. And it becomes uncontrollable and dangerous for the authorities.

Along with this, the growth of private capital increases the share of the 'Precariat'. Business creates new jobs, but aspiring to get more profit tends to attract cheap labor to work, finding it among migrants, trainees and students. Business seeks to use labor more efficiently, and therefore reduces the number of employees. Business also seeks to use contingent labor. All this, on the one hand, creates additional jobs. On the other hand, it creates instability of employment.

The question whether the employment is threatening the national economy or is threatened by the dependence of more than half of the population on the national budget has required the authors to look differently at the social structure of the society.

M. Savage, F. Devine, N. Cunningham, M. Taylor, Y. Li, J. Hjellbrekke, B. Le Roux, S. Friedman \& A. Miles (2013) based on the Nuffield class schema showed that at low levels of the class structure, along with the traditional working class, there is a 'Precariat', characterized by a low level of capital [2].

In recent studies, some features of the 'Precariat' have been identified that are manifested in the Philippines (Ofreneo, 2013) [3], in the Yugoslav Successor States (Baker, 2014) [4], in European societies (Pajnik, 2016) [5], in Portugal (Matos, (2012) [6], in Japan national labor markets (Inui, 2015) [7], in education (Courtois, 2015) [8], in tourism (Lee, 2015) [9], in sport of high achievements (Agergaad, 2016) [10].

The theoretical substantiation of the 'Precariat' is found in the works by K. Siegmann \& F Schiphorst [11], T. Brass [12], O. Shkaratan, V. Karacharovskiy \& E. Gaziukova [13].

L. Wasquant speaks about the 'Precariat' as a new form of poverty that are neither residual, nor cyclical or transitional, but inscribed in the future of contemporary societies [14]. 
M. Quinlan writes about the similarity of terms 'contingent work' and 'precarious employment'. He has pointed to both the immediate and broader social effects of precarious employment [15].

G. Standing has published a number of works showing the problems of the 'Precariat' $[16,17,18]$. G. Standing calls the 'Precariat' a new dangerous class [16]. However, R. Munck warns us against this approach. He writes that «we should avoid the language of 'dangerous class', as deployed by Guy Standing» [19].

In this regard, the question arises whether the 'Precariat' is a social problem for Russia or is it a new reality?

The purpose is search for an answer to the question of whether the 'Precariat' is a social problem for Russia or is it a new reality?

First, we analyzed changes in the salaries of Russian workers over the past 20 years. Then we recalculated this data into USD and Euro and compared the results. The results of the analysis made it possible to question the income as a sign of referring to the 'Precariat' and to put forward a sign of employment.

Then we analyzed the number of all employed by type of activity and identified the proportion of employees who depend on the state budget of Russia. To this number, we have attributed still some categories of the population and the ecosystem of the employed.

Further comparisons with the population attributable to the 'Precariat' allowed us to allocate a new phenomenon as the 'Dependiat'.

\section{RESULTS}

J. Toshchenko notes that in Russia as well as all over the world, at the end of the 20th and beginning of the 21st century a new social class appeared - a precarious character characterized by temporary or part-time employment, which is permanent, permanent and sustainable [20]. J. Toshchenko distinguishes seven following basic groups of the population shaping the basis of the 'Prekariat'.

a) part of the able-bodied population permanently employed in temporary work;

b) people working part-time or intermittent seasonal or accidental earnings;

c) the unemployed (Volovskaya, 2015) [21]; [22];

d) representatives of creative professions (Davydov, 2014)

e) employed by contingent labor (Kozina, 2013) [23];

f) migrants (Malakhov, 2015) [24];

g) interns and students.

Indeed, the 'Precariat' is now represented by all layers of modern society and is therefore heterogeneous. Therefore, the quantitative assessment of the 'Precariat' in various studies varies from a few percent to a third of the Russian population.
Apparently, the basis for stratification of the population should not be income, but the stability of employment and confidence in the future. After all, official statistics show an increase in the nominal wages of Russian citizens (Fig. 1).

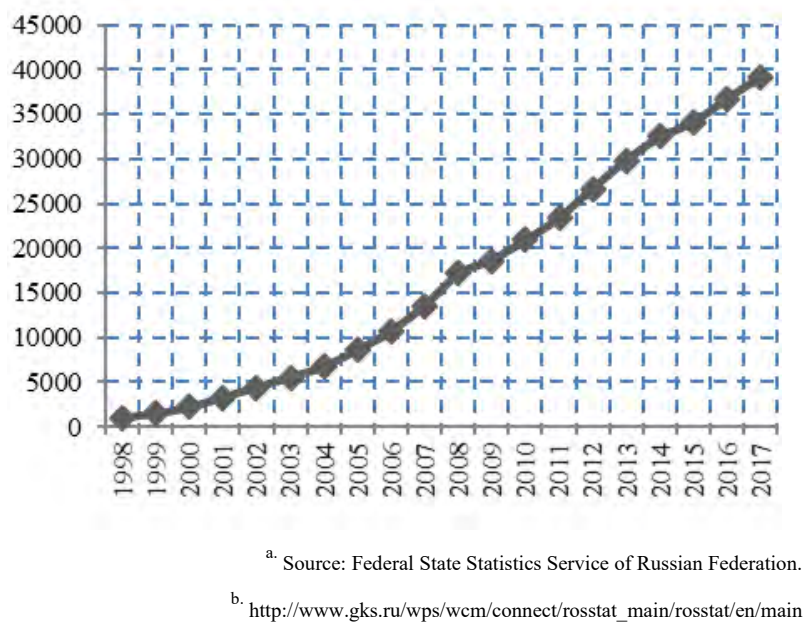

Fig. 1. Average monthly nominal accrued wages of employees as a swhole for the economy of the Russian Federation in 1998-2018, rubles.

At the same time, in terms of US dollars or Euro, the picture looks somewhat different (Fig. 2). We observe a significant fall in wages in terms of USD or Euro in 20142016.

In a sense, the income of the population does not reflect the real picture. Thus, the number of poor in Russia fluctuates around 20 million people. This is $13 \%$ of the country's population. The real poor are much larger. Monetary calculation, which is tied to the subsistence level, is not entirely correct.

It is not the income that is to be considered, but the real opportunities for people to receive education, to buy medicine, to go on vacation and to get other benefits. Therefore, a deprivation approach should be added to the monetary approach. In this case, we can determine that part of the population that can not afford to buy that part of the goods or services that becomes a regular set. If we apply the deprivation method (deprivation method), then the poverty level in Russia will be $25 \%$ (about 36 million people). This is twice the official statistics.

According to the Labor Force Survey (March 2018), among the population of Russia aged 15 and over, the labor force comprised 76.1 million people, or $52 \%$ of the total population of the country, of which 72.3 million were employed in the economy and 3.8 million people had no occupation, but actively sought it out. 


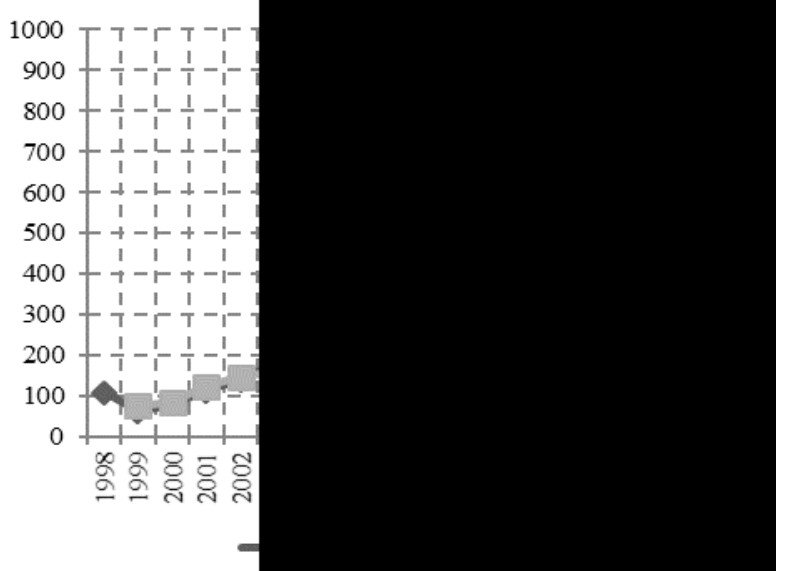

c. Compiled by the author on the basis of data in Fig. 1 in terms of data of the Central Bank of Russia URL: https://bankiros.ru/currency

Fig. 2. Average monthly nominal accrued wages of workers in the whole of the economy of the Russian Federation in 1998-2018, USD and Euro.

The distribution of the employed population of Russia by types of activity is shown in Fig. 3.

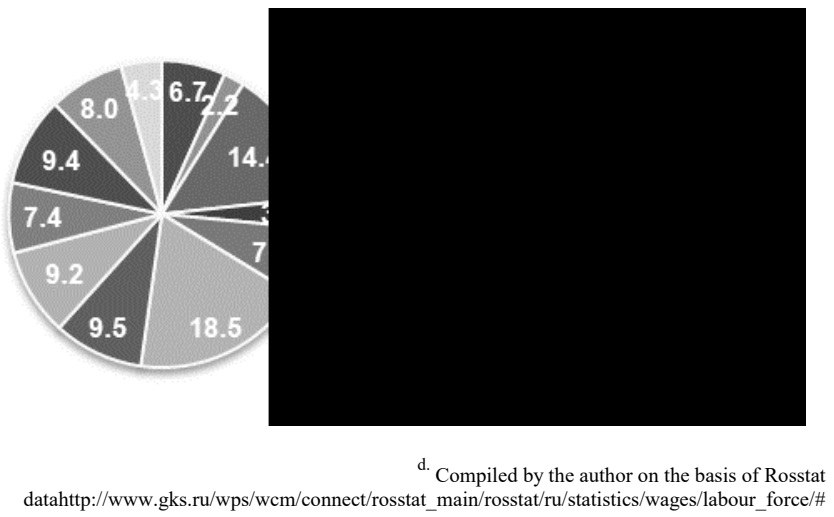

Fig. 3. Distribution of the employed population of Russia by type of activity, percentage.

If you summarize the employed in health $(8.0 \%)$, education (9.4\%) and public administration (7.4\%), then the share of workers depending on the state budget will be about $25 \%$ of all employed in the economy.

In reality, those depending on the state budget in Russia are more numerous. So, we calculated $25 \%$ of all employed in the economy is about 18 million people. Add to this 4 million unemployed and 46 million pensioners, we get at least 68 million people. And if add to this the members of their families, that is, those whose welfare depends on income, the amount depending on the state budget may exceed 100 million people. This is with a population of 146 million people.

In this sense, the values of survival prevail over the values of development for more than 100 million citizens of Russia. To increase the picture of the prevalence of survival values, poverty centers among 5 million people employed in agriculture $(6.7 \%)$.
The survey by O. Petrashchak, I. Kolosinskyi, M. Kolosinska, V. Marych (2017) shows that such factors as job stability, pay rate increase are underestimation [25].

Obviously, the obtained results on the number of people depending on the national budget in Russia many times exceed the population of Russia attributed by J. Tishchenko to the 'Precariat'. This allows us to define a new phenomenon - the 'Dependiat'.

The 'Dependiat' is characterized by employment, which is permanent, stable, paid out of the national budget in the amount close to the poverty line.

\section{CONCLUSION}

V. Putin signed a new, so-called, May decree immediately after the inauguration. In his decree 'On national goals and strategic tasks for the development of the Russian Federation until 2024', among the nine main goals, the goal is to ensure a steady growth of real incomes of citizens, as well as the growth of the pension provision level above the inflation level, and the goal of halving the level of poverty in the Russian Federation.

In our opinion, a large proportion of the 'Dependiat' in the population of the country will remain the main social problem of the population of Russia. After all, the full dependence of personal income on the national budget in conditions of its limited and insufficient state cannot take more than a quarter of the country's population out of a difficult financial situation.

Official statistics show that the share of the poor in Russia is $13.8 \%$ (Fig. 4), and the proportion of Russians in serious condition is estimated at $24.6 \%$. We found that the fight against poverty will consist in changing the set and amounts of payments to employees and the introduction of new payments from the national budget.

Refusing the so-called 'labor rights' and social rights that extended to industrial citizenship of the twentieth century, the growing 'Precariat' needs new systems of regulation, social protection and redistribution.

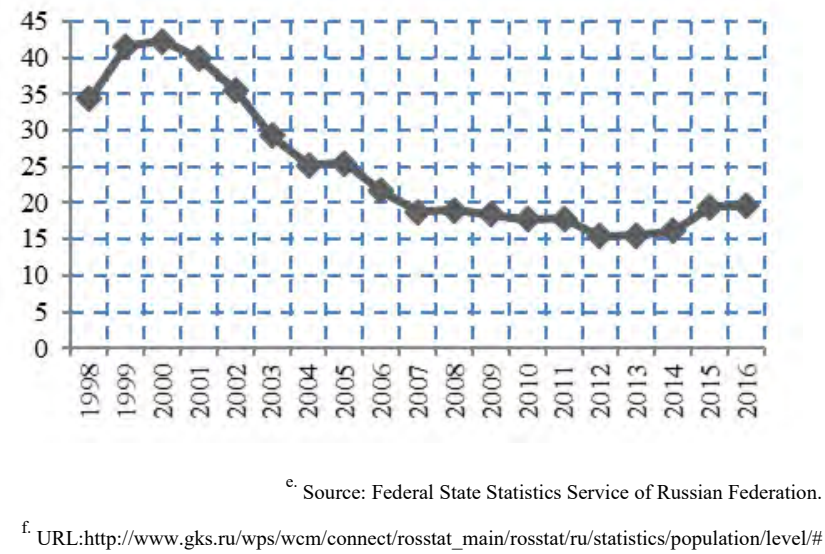

Fig. 4. The number of Russia's population having incomes lower than the minimum of subsistence in 1998-2016, million people. 
G. Standing (2014) conceders that 'denied so-called 'labour rights' and social entitlements that went with twentieth century industrial citizenship, the growing Precariat needs new systems of regulation, social protection and redistribution' [18].

In our opinion, the 'Dependiat', unlike the 'Precariat', does not need new social protection and redistribution systems, but in new systems of transition from macroeconomic models of perception of reality to microeconomic models of economic behavior.

At the same time, the authors consider that the following families should remain among those who are dependent on the budget:

a) large families;

b) guardian and adoptive foster families;

c) families having a child with disabilities;

d) families in which mothers are over 50 years of age.

It is these families that need new regulation systems, social protection and redistribution.

The problems of the social protection of some families were described by us in the works [26, 27]. Therefore, we did not dwell on this here.

\section{RERERENCES}

[1] L. Pasechko and A. Sapronov, "Poverty in Russia: theoretical and methodological issues of research," Economic Annals-XXI, vol. 165(56), pp. 27-30, 2017.

[2] M. Savage, F. Devine, N. Cunningham, M. Taylor, Y. Li, J. Hjellbrekke, R.B. Le, S. Friedman, and A. Miles, "A New Model of Social Class? Findings from the BBC's Great British Class Survey Experiment," Sociology, vol. 47, pp. 219-250, 2013.

[3] R. Ofreneo, "Precarious Philippines: Expanding Informal Sector, "Flexibilizing" Labor Market," American Behavioral Scientist, vol. 57, pp. 420-443, 2013.

[4] C. Baker, "The Local Workforce of International Intervention in the Yugoslav Successor States: 'Precariat' or 'Projectariat'? Towards an Agenda for Future Research," International Peacekeeping, vol. 21, pp 91-106, 2014

[5] M. Pajnik, "Wasted precariat': Migrant work in European societies," Progress in Development Studies, vol. 16, pp. 159-172, 2016.

[6] P. Matos, "Call center labor and the injured precariat: Shame, stigma, and downward social mobility in contemporary Portugal," Dialectical Anthropology, vol. 36, pp. 217-243, 2012

[7] A. Inui and A. Higuchi, "Entering the precariat: Young people's precarious transitions in Japan," Handbook of Children and Youth Studies, pp 583-606, 2015
[8] A. Courtois and T. O'Keefe, "Precarity in the ivory cage: Neoliberalism and casualisation of work in the Irish higher education sector," Journal for Critical Education Policy Studies, vol. 13, pp. 43-66, 2015.

[9] D. Lee, M. Hampton, and J. Jeyacheya, "The political economy of precarious work in the tourism industry in small island developing states," Review of International Political Economy, vol. 22, pp. 194-223, 2015 .

[10] S. Agergaard and C. Ungruhe, "Ambivalent Precarity: Career Trajectories and Temporalities in Highly Skilled Sports Labor Migration from West Africa to Northern Europe," Anthropology of Work Review, vol. 37, pp 67-78, 2016.

[11] K. Siegmann and F. Schiphorst, "Understanding the globalizing precariat: From informal sector to precarious work," Progress in Development Studies, vol. 16, pp. 111-123, 2016.

[12] T. Brass, "Free Markets, Unfree Labour: Old Questions Answered, New Answers Questioned," Journal of Contemporary Asia, vol. 45, pp. 531$540,2015$.

[13] O. Shkaratan, V. Karacharovskiy, and E. Gaziukova, "Precariat: Theory and empirical analysis (polls in Russia, 1994-2013 data)," Sotsiologicheskie Issledovaniya, vol. 12, pp. 99-110, 2015.

[14] L. Wasquant, "Territorial Stigmatization in Age of Advanced Marginality," Thesis Eleven, vol. 91,pp. 66-77, 2007.

[15] M. Quinlan, "The 'Pre-Inventation' of precarious employment: The changing world of work in context," Economic and Labour Relations Review, vol. 23, pp. 3-24, 2012.

[16] G. Standung, The Precariat. The New Dangerous Class, London: Bloomsbury Publishing Plc. ,2011.

[17] G. Standung, "The precariat: From denizens to citizens?” Polity, vol. 44, pp. 588-608, 2012.

[18] G. Standing, "Understanding the precariat through labour and work," Development and Change, vol. 45, pp. 963-980, 2014.

[19] R. Munck, "The precariat: A new from the South," Third World Quertetly, vol. 34, pp. 747-762, 2013.

[20] Zh. Toshchenko, "Precariat - a new social class," Sociologicheskie Issledovaniya, vol. 6, pp. 3-13, 2015 (in Russ.)

[21] N. Volovskaya, L. Pliusnina, A. Rusina and A. Inizemtseva, "Unemployed population and self-employment in Siberian region," Sociologicheskie Issledovaniya, vol. 5, pp. 52-60, 2015 (in Russ.).

[22] A. Davydov, "Zinaida Golenkova and Russian Sociology," Philosophskie nauki, vol. 10, pp. 123-136, 2014 (in Russ.).

[23] I. Kozina, "Workers of borrowed labor," Sociologicheskie Issledovaniya vol. 5, pp. 19-31, 2013 (in Russ.).

[24] V. Malakhov, "Immigrants as Social Agents: Allochtones and Autochtones," Polis. Political Studies, vol. 1, pp. 111-125, 2015 (in Russ.).

25] O. Petrashchak, I. Kolosinskyi, M. Kolosinska, and V. Marych, "Youth satisfaction with the employment: a survey," Economic Annals-XXI, vol. 166(7-8), pp. 96-99, 2017.

[26] A. Maloletko, The approaches to methods and mechanisms of formation of the national risk management system of socio-economic development and ensuring the economic security of the state, Economic and Social Development, 25th International Scientific Conference on Economic and Social Development - "XVII International Social Congress (ISC-2017), ISSN 1849-7535, 2017, pp 567-575.

[27] V.I. Tinyakova, A.N. Maloletko, O.V. Kaurova, M.V. Vinogradova, and A.A. Larionova, Model of Evaluation of Influence of Globalization on the National Stock Market, Contribution to Economics, 2017, pp 261272. DOI: 10.1007/978-3-319-55257-6 35. 